\title{
Notes
}

1 Matthew Gager's Dido and Marlowe's Dido, Queen of Carthage (Early Drama at Oxford and Edward's Boys, Christ Church Banqueting Hall, Oxford 21 September), the Chester Mystery Plays (Chester Cathedral, 26 June-13 July), A Satire of the Three Estates (Staging and Representing the Scottish Renaissance Court project, Linlithgow Palace, 7-9 June), the Chester Noah Play (Liverpool University Players, Liverpool Maritime Museum, 4 May) and Gorboduc (Read Not Dead, Inner Temple, 28 April) are just a sample of early drama performed in the UK in 2013.

2 See, for example, Janette Dillon, The Language of Space in Court Performance, 1400 1625 (Cambridge, 2010) and Theatre, Court and City, 1595-1610: Drama and Social Space in London (Cambridge, 2006); Julie Sanders, The Cultural Geography of Early Modern Drama, c. 1620-1650 (Cambridge, 2011); Michal Kobialka, 'Staging Place/ Space in the Eleventh-Century Monastic Practices' and Donnalee Dox, 'Theatrical Space, Mutable Space and the Space of Imagination: Three Readings of the Croxton Play of the Sacrament', Barbara A. Hanawalt and Michal Kobialka (eds), Medieval Practices of Space (Minneapolis, 2006), 128-48 and 167-98.

\section{Christopher Marlow. Performing Masculinity in English University Drama, 1598-1636. Farnham, Surrey: Ashgate, 2013. Pp 186.}

ELIZABETH SANDIS

Early Theatre 17.1 (2014), 201-205

Merton College

University of Oxford

DOI: http://dx.doi.org/10.12745/et.17.1.11

In the introduction to this new study of early modern English drama, Christopher Marlow rightly emphasizes the neglected state of academic drama, university drama in particular, and his own study is a welcome contribution to the field. Constructing his argument around the idea of 'scholarly masculinity' (7), Marlow develops this concept in various directions to demonstrate the 'range of versions of maleness performed by university students' (16) and to explore the world of sixteenth- and seventeenth-century higher education both on and off the stage. The idealism of scholarly rigour in tension with the reality of human frailty produces many interesting effects on the academic stage, and readers will find Marlow's volume rewarding. One 
significant concern, however, is that he does not show engagement with texts other than those written in the English language, perpetuating neglect of the Latin works so important to the bilingual culture of learning at early modern universities.

Marlow anticipates the reader's surprise that his study of student drama at Oxford and Cambridge opens with a reading of Robert Greene's Friar Bacon and Friar Bungay, 'not a university play' (16) but a professional piece written for a fee-paying London audience. This starting point is engaging, not least because Greene's own university experience (as a student of St John's College, Cambridge) colours his portrayal of academe, which centres upon the life of thirteenth-century Oxford man Roger Bacon, philosopher, Franciscan friar, and reputed necromancer. Greene's play has much to offer, and Marlow's brief treatment is generalizing rather than detailed, but he signposts some enticing examples for the reader to follow up, such as the opening to scene 7 which presents academics discussing the necessity for entertainments to be laid on in honour of King Henry and the emperor of Germany who are soon to visit Oxford. The remainder of the chapter is a useful orientation exercise guiding the reader towards the particular conditions and experiences shaping student life at Oxbridge and noting 'the specificity of that environment' (15) in contradistinction to our own twenty-first-century set-up. The average age of students, for example ('most Oxbridge students really were young men, most of whom would be considered too young to be admitted to a university today', 22), is a salient point for the discussions which follow, not least chapter 5's study of The Christmas Prince revels of 1607/8, a season of entertainments characterized by the hit-and-miss quality of youthful inexperience.

Neatly side-stepping an in-depth look at pedagogical trends of the period, Marlow emphasizes the lack of adherence to an 'official curriculum' for BA and MA courses at the universities before moving swiftly on to questions of social mobility and interclass friendships. On the one hand, he is to be credited for taking an inclusive approach to the varieties of dramatic performance, ensuring that important activities such as the young men's participation in disputations receive a mention ('semi-improvised events that can also be understood as theatrical occasions', 33). On the other, his statement that these disputations functioned as 'one of the key pedagogical tools employed by Oxford and Cambridge to test their students' mettle' is a throwaway line unqualified by any mention of Latin as the language of performance and the rhetorical practices designed to test scholars' fluency and style. 
Returning to the pedagogical value of drama a few pages later, his interjection 'Indeed, some argued that English plays or comedies in general had only a very slight beneficial effect, if any at all, on the students involved in acting or performing' (41) raises hopes of further discussion (it would be interesting to compare the relative benefits of English and Latin, tragedy and comedy at this point), but this is not forthcoming. Instead, a light touch on the important Gager-Rainolds debate introduces, almost by accident, a reference to two of the key Latin texts which informed the experience of the early modern scholar and the traditions of university drama, via the standard passage so often quoted in which Gager champions the academic aims of university drama: 'to recreate owre selves, owre House, and the better parte of the Vniuersitye, with some learned Poëme or other; to practyse owre owne style eyther in prose or verse; to be well acquaynted with Seneca or Plautus', and so on (42). We might, in a study devoted to 'scholarly masculinity', have expected some comment to complement the quotation (perhaps explicating contemporary Elizabethan assessments of 'style' in relation to classical principles) or a few examples of the kind of imitations of Senecan tragedy and Roman comedy which university students were encouraged to write and perform. Gager's own neo-Senecan productions at Christ Church, Oxford earned him a reputation as the leading dramatist of the university in the 1580s and 1590s, though his plays are not discussed in Marlow's volume. Nor is this omission justified by the fact that Gager wrote in Latin (the obvious choice for his purposes); we cannot afford to avoid engaging with such texts, and if close textual analysis in the original does not seem an option, there are excellent resources available offering easier routes in. When we consider the free access provided by the translations and commentaries of The Philological Museum online, Marlow's emphasis upon the inaccessibility of Latin texts on page 1 of his volume seems rather overstated, and risks discouraging others from approaching a field that cannot sensibly be discussed without embracing its bilinguality. ${ }^{1}$

Chapter 2, 'Town and Country', plays to Marlow's strengths with readings of four Cambridge plays from the turn of the seventeenth century exploring interactions between the university man and the world outside. His analysis of the anonymous Club Law, performed at Clare Hall, carefully contrasts the subtleties of characterization on offer in the play against the apparent triumph of the scholarly camp over the uneducated locals. Now into the swing of things, Marlow's study of the confusion and disillusionment of the scholar characters in the Parnassus trilogy is lively and detailed. 
Chapter 3 introduces 'real-life' examples of misbehaving masculinity as the backdrop to staged dramatizations of misrule, positing the anonymous show 'Preist the Barbar' as a critique of the riots which took place in Cambridge in 1610/1. This discussion is sandwiched between readings of Thomas Randolph's Cambridge comedy Aristippus and the three productions for King Charles's visit to Oxford in 1636: William Cartwright's The Royal Slave, William Strode's The Floating Island, and George Wilde's Love's Hospital. These plays are thematically united, reflecting on the right to rule, self-governance, and responses to authority, and Marlow presents sensitive analysis which allows the ambiguities and contradictions embedded in these plays to be appreciated.

Royal plays dominate once again in chapter 4, with readings of Peter Hausted's The Rival Friends and Thomas Randolph's The Jealous Lovers (both commissioned to entertain Charles on his visit to Cambridge in 1632) alongside Mead's The Combat of Love and Friendship (ca 1635). Marlow has selected these plays in order to consider dramatic representations of the competing merits of love and friendship and, more specifically, 'the classical view of perfect friendship' (113); and thus it would be worthwhile to compare contemporary university plays where the dramatist has engaged more conspicuously with classical models in his choice of language and form. A case in point is George Wilde's ironizing treatment of Senecan passions and the traditions of Roman comedy in Eumorphus sive Cupido Adultus (1635), composed the year before his Love's Hospital. Through a series of encounters with both men and women, Eumorphus learns the skin-deep limits of his own beauty and the superficialities of passion, and by the end of the play he reaffirms his commitment to celibacy and extols the superiority of friendship between men. In giving up his love Pasithea to Pamphilus his friend, he precipitates the conventional comic solution of a male-female marriage, but simultaneously rejects it for himself. It would be interesting to consider how Eumorphus, both the character and actor playing the part, stands up to the ideals of 'scholarly masculinity' as defined by Marlow.

The final chapter is a game of two halves, and it begins by introducing us to the world of college initiation ceremonies. Focusing on the tradition of performing speeches know as 'saltings' (whereby first years were introduced to the community by their second- or third-year 'fathers'), Marlow directs us to the sophistications of the form as it had developed by the time Thomas Randolph and John Milton made their contributions in Cambridge in the late 1620 s. He demonstrates how the ceremony had outgrown its origins as a 
parody of university and college officialdom and suggests the ways in which the student performers engaged their audience in a process of self-reflective questioning. Marlow rightly does not restrict himself to the English portions of Randolph and Milton's works, but investigates the Latin sections of the speeches through the medium of Freidberg and Hale's translations respectively (though it seems unhelpful that he does not let readers view the Latin passages too). In trying to unravel the nuances at play in Milton's Latin text he shrewdly compares different translations for key words (154-5), which proves to be a fruitful approach and one which could have been deployed elsewhere in the book to good effect. The second half of this chapter is a case in point; having decided to focus on the 1607/8 season of revels at St John's College, Oxford (often referred to as The Christmas Prince), Marlow makes it clear that he intends to siphon off 'the English plays and narrative portions of Prince' (13) for discussion, leaving the Latin entertainments (which significantly outnumber those in English) without exploration or even outline. The reader is therefore liable to come away with an inaccurate sense of the season of entertainments as a whole, even though his readings of Time's Complaint, The Seuen Dayes of the Weeke, Periander, and The Vigilate are very insightful.

Accessible and engaging, Marlow's thought-provoking analysis suggests the potential for opening up the field and taking a closer look at this rich body of material. It also highlights the need for a bilingual approach to fit the nature of the evidence itself. The valuable contribution which Marlow makes will hopefully entice others into the field and generate some interesting debates in the years to come.

\section{Notes}

1 See The Philological Museum, http://www.philological.bham.ac.uk/. 